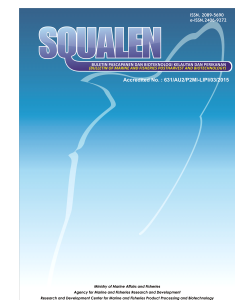

\title{
Characteristics and Use of Peptones from Catfish (Clarias gariepinus) and Pangas Catfish (Pangasius pangasius) Heads as Bacterial Growth Media
}

\author{
Dwi Setijawati ${ }^{1,2}$, Abdul Aziz Jaziri ${ }^{1,2,3^{*}}$, Hefti Salis Yufidasari ${ }^{1,2}$, Mohammad Dwi Pratomo ${ }^{1}$, Dian Wahyu Wardani ${ }^{1}$, \\ Dinda Ersyah1, and Nurul Huda ${ }^{4,5^{*}}$ \\ ${ }^{1}$ Faculty of Fisheries and Marine Science, Universitas Brawijaya, Malang 65145, Indonesia. \\ ${ }^{2}$ Bioseafood Research Group, Faculty of Fisheries and Marine Science, Universitas Brawijaya, Malang 65145, Indonesia. \\ ${ }^{3}$ Halal Thoyyib Science Center, Universitas Brawijaya, Malang 65145, Indonesia \\ ${ }^{4}$ Faculty of Food Science and Nutrition, Universiti Malaysia Sabah, Kota Kinabalu, Sabah, 88400, Malaysia \\ ${ }^{5}$ Adjunct Professor, Universitas Sultan Ageng Tirtayasa, Serang 42124, Banten, Indonesia
}

Article history:

Received: 9 January 2020; Revised: 16 April 2020; Accepted: 6 May 2020

\begin{abstract}
Peptone is a hydrolysate product rich in amino acids, and it is uncoagulated at high temperature. Commercial peptone produced from land animals cannot be declared as acceptable in terms of lawfulness due to religious concerns. Catfish (Clarias gariepinus) and pangas catfish (Pangasius pangasius) are important species for the fish processing industry in Indonesia. The filleting process resulted in value by-products. The fish head as the byproducts can be utilized as a main raw material for higher economic value products, such as peptone. The aim of this study was to characterize peptones extracted from the heads of catfish and pangas catfish with different acid conditions. The characteristics of chemical composition, yield, color parameter, solubility, amino acid content, bacterial growth rate and biomass production were observed. The catfish peptone (CFP) and pangas catfish peptone (PCP) obtained with different acid conditions showed high protein content in the range of $84.35 \%$ to $90.80 \%(\mathrm{P}<0.05)$. The yields of CFP and PCP were significantly different $(\mathrm{P}<0.05)$ and varied between $4.75 \%$ and $5.66 \%$. The solubility of treated peptones varied between $98.03 \%$ and $99.52 \%$, and the peptones were rich in glycine, glutamic acid, proline and leucine. Bacterial growth test showed that both CFP and PCP had better growth rates compared to the commercial peptone tested in this study. In addition, the biomass production with peptone from catfish and pangas catfish was higher than that with the commercial product $(P<0.05)$. This research proposed that catfish and pangas catfish heads could be developed as an alternative source for peptone production.
\end{abstract}

Keywords: peptone, fish by-product, acid-assisted extraction, growth rate, biomass production

\section{Introduction}

Indonesia is the third largest country in terms of total aquaculture production (FAO, 2018). In 2017, its production reached 17.22 million tons, and an increase of approximately 37 million tons in 2030 was projected (Ministry of Marine Affairs and Fisheries, 2017). Catfish (Clarias gariepinus) and pangas catfish (Pangasius pangasius) are aquaculture commodities with high productivity rates. The average growth of catfish and pangas catfish production in Indonesia increased $56.32 \%$ and $31.76 \%$ from 2015 to 2018 , respectively. The total catfish production reached 841.75 thousand tons in 2017 and increased by approximately 1.81 million tons in 2018 due to the biofloc program. The production of pangas catfish increased from 245.75 thousand tons in 2017 to 492 thousand tons in 2018 (Ministry of Maritime Affairs and Fisheries, 2018). Both catfish and pangas catfish are commercially important species from an industrial point of view. They are usually used for fillet production as raw materials in meatballs, fish cakes, nuggets and other diversified fish products; meanwhile, byproducts, especially the head portion, are used as low added-value products. The heads of catfish and pangas catfish weigh approximately $27.49 \%$ and $43.28 \%$ of the total catfish weight, respectively (Ningsih et al., 2011). These by-products can be served

${ }^{*}$ Corresponding author.

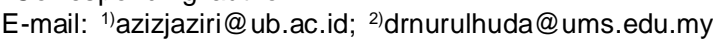

Copyright (C) 2020, Squalen BMFPB. Accreditation Number: 21/E/KPT/2018.

DOI: http://dx.doi.org/10.15578/squalen.v15i1.437 
as peptone products as it more profitable and marketable than other diversification products. On the other hand, utilization of their by-products could minimize serious environmental problems (Herpandi et al., 2011).

Peptone is a hydrolyzed product rich in amino acids that is uncoagulated at high temperatures (Shirahigue et al., 2018). According to the Global Peptone Market Report (2019), the global market of peptone reached USD 262.0 million in 2014 and slightly increased by approximately USD 271.0 million in 2019. Indonesia imported 5.102 tons of peptone in 2013 , with a value of USD 20.76 million. The number increased since 2012, it was reported that during the time 3.296 tons of peptone or equal to USD 12.15 million was imported (Statistics Indonesia, 2014). In order to meet the demand of the peptone market, fish by-products are promising raw materials for producing peptone. In addition, marine-based by-product materials are available in a large amount yielded from the production, and they are also acceptable among religious beliefs, due to the halal issue of commercial peptones (Setijawati et al., 2019; Jaziri et al., 2020).

As a hydrolyzed product, peptone from fish byproducts can be generated by enzyme- and acidassisted extraction methods. In enzymatic extraction process, proteins are cleaved into smaller amino acids at specific peptide bonds. However, its drawbacks are slow reaction rate and high cost, particularly for industrial scale (Khalil, 2012). In contrast, the acidassisted extraction method has advantages, such as inexpensive cost, short extraction time, smooth operation, and applicability to industrial scale (See et al., 2011). Benites et al. (2011) stated that the selection of an acidifying agent is based on three factors: cost, availability, and bactericidal action. Moreover, considering the acceptability (lawfulness) point of view, acid solutions are mostly categorized into positive list of compounds. Najim et al. (2015) reported that peptone extracted from fish waste with hydrochloric acid $(\mathrm{HCl})$ had a higher nitrogen content $(10.8 \%)$ compared to peptone extracted using sodium hydroxide $(\mathrm{NaOH})$.

Peptone contains nitrogen compounds derived from amino acids, supporting microbial culture (Aspmo et al., 2005). Several research studies have explored whether peptone extracted from fish by-products could improve the microbial growth rate and biomass production. Shirahigue et al. (2018) reported that peptones extracted from tilapia (Oreochromis niloticus) and cobia (Rachycentron canadum) waste with different acid combinations significantly improved the growth rate and biomass production of Escherichia coli and Staphylococcus aureus cultures compared to commercial peptone. Moreover, Poernomo and
Buckle (2002) reported that peptone isolated from cowtail ray (Trygon sephen) viscera was able to support the microbial growth rate of Bacillus subtilis, Escherichia coli, Staphylococcus aureus and Saccharomyces cerevisiae cultures. Deraz et al. (2011) used tilapia viscera for peptone production and showed a high biomass production. Srikandace et al. (2017) reported that peptone extracted from kerong fish (Terapon jarbua) showed a higher growth rate in E. coli compared to commercial peptone. These findings are also in line with the peptone isolated from Atlantic cod (Gadus morhua) stomach with formic and phosphoric acid reported by Gildberg et al. (2010). To be concluded, fish peptones increase the microbial growth rate and biomass production due to the high content of soluble protein, particularly nitrogen compounds.

Few studies have documented that peptone extracted from catfish and pangas catfish heads with acid combinations suppressed bacterial growth rate and biomass production. Therefore, this study proposed to analyze the characteristics of peptone produced from the heads of catfish (C. gariepinus) (CFP) and pangas catfish (P. pangasius) (PCP) under different acidic conditions and to evaluate their suitability as microbial growth media for Staphylococcus aureus and Escherichia coli.

\section{Materials and Methods}

\subsection{Materials}

The catfish (C. gariepinus) heads were collected from a fishery and processed at home industry located in Singosari (Malang, East Java, Indonesia), and the pangas catfish ( $P$. pangasius) heads were obtained from CV. Room located at Industrial Park (Sidoarjo, East Java, Indonesia). The average sizes of the catfish heads were approximately 70-90 g per sample, and the pangas catfish heads weighed approximately 90 $100 \mathrm{~g}$ per sample. The fish head were packed into plastic bags and kept under cold conditions in an insulated cool box with ice during transportation (approximately 1-2 h) to the laboratory of fishery product technology at the Faculty of Fisheries and Marine Science, Universitas Brawijaya. Upon arrival, the fish heads were washed in running tap water and then grounded using a milling machine (MHW-80, Indonesia). The grounded samples were placed in polyethylene plastic bags and stored in a freezer at $20^{\circ} \mathrm{C}$ for up to 14 days. The bacteria (E. coli and $S$. aureus strains) used in this study were purchased from InaCC LIPI, Indonesia. Commercial meat-based peptone (Merck) was used for comparison. Only the analytical grade of chemicals and reagents were used. 


\subsection{Preparation of Peptone Production}

The production of peptone was carried out using the method of Shirahigue et al. (2018) with slight modifications. The frozen grounded fish head (catfish and pangas catfish) were thawed with tap water. After complete thawing, approximately $900 \mathrm{~g}$ of sample was weighed, and $100 \mathrm{~mL}(10 \%, \mathrm{v} / \mathrm{w})$ of distilled water was added. Both catfish and pangas catfish heads were treated with $1.5 \%(\mathrm{v} / \mathrm{m})$ acid combinations of propionic and formic acids at ratios of 1:2, 1:3, and 1:4 (v/v). The $\mathrm{pH}$ of the solutions was adjusted to approximately 4.2 for acid hydrolysis process for 7 days at room temperature $\left(24-27^{\circ} \mathrm{C}\right)$, and the solutions were manually stirred each day. The hydrolysis reactions were terminated at $85^{\circ} \mathrm{C}$ for $20 \mathrm{~min}$, and the solutions were centrifuged at 5,000 rpm for $10 \mathrm{~min}$ to separate the lipid, aqueous, and pellet fractions. After centrifugation, the aqueous phase was transferred into a glass jar and stored at $4^{\circ} \mathrm{C}$ for $24 \mathrm{~h}$. The soluble samples were spray-dried at an inlet temperature of $160^{\circ} \mathrm{C}$ and an outlet temperature of $90^{\circ} \mathrm{C}$. The obtained peptones were stored at a low temperature $\left(4^{\circ} \mathrm{C}\right)$ prior to use.

\subsection{Chemical Composition Analysis}

The chemical compositions of catfish and pangas catfish head materials and catfish peptone (CFP) and pangas catfish peptone (PCP) samples were determined according to the method of the Association of Official Analytical Chemist (AOAC, 2000). The Kjeldahl method was used to measure the crude protein from both raw materials and peptone samples, whereas fat content was analyzed using the Soxhlet extractor method. The moisture and ash contents of the samples were measured by the gravimetric method.

\subsection{Measurement of Yield}

The yield of peptone extracted from the catfish and pangas catfish heads was measured using the following formula:

$$
\text { Yield }(\%)=\frac{M}{M o} \times 100
$$

where $M$ is the weight of peptone $(\mathrm{g})$ obtained after drying, and $M o$ is the weight of the catfish and pangas catfish raw materials $(\mathrm{g})$.

\subsection{Measurement of Color Parameter}

The color parameter of peptone isolated from the heads of catfish (CFP) and pangas catfish (PCP) was measured using a Konica minolta chromameter CR-
400 (Japan). The results were expressed as $L^{*}, a^{*}$, $b^{*}$, color intensity, and whiteness, where the $L^{*}$ indicates lightness, $a^{*}$ indicates redness, and $b^{*}$ indicates yellowness.

\subsection{Measurement of Solubility}

The solubility of peptone extracted from the heads of catfish (CFP) and pangas catfish (PCP) was determined by the gravimetric method (Ningsih et al., 2018). Moisture content (MC) should be determined before measuring solubility. Filter paper was dried for $3 \mathrm{~h}$ at $105^{\circ} \mathrm{C}$ (a). A $1 \mathrm{~g}$ sample (c) was dissolved in $150 \mathrm{~mL}$ of distilled water and then filtered using Whatman no. 42 filter paper. Then, the filter paper was weighed (b). The solubility of the peptone samples was calculated by the following equation:

$$
\text { Solubility }(\%)=\frac{100-(b-a)}{(100-M C) \times c} \times 10 a
$$

\subsection{Measurement of Amino Acid Composition}

The amino acid composition was determined using ultra-pressure liquid chromatography (UPLC) according to the method of Nollet and Fidel (2015). Approximately $5 \mathrm{~mL}$ of $\mathrm{HCl} 6 \mathrm{~N}$ was added to $0.1 \mathrm{~g}$ of sample. The sample was hydrolyzed at $110^{\circ} \mathrm{C}$ for $22 \mathrm{~h}$. The hydrolyzed sample was transferred to distilled water. Afterwards, the mixture was filtered with a $0.45 \mu \mathrm{m}$ filter. The $500 \mu \mathrm{L}$ filtrate was mixed with $40 \mu \mathrm{L}$ of ABBA and $460 \mu \mathrm{L}$ of aquabidest. Then, $10 \mu \mathrm{L}$ of the solution was added to $70 \mu \mathrm{L}$ of AccQ Fluorine Borate and 20 $\mu \mathrm{L}$ of fluorine. The homogenized solution was incubated at $55^{\circ} \mathrm{C}$ for $10 \mathrm{~min}$. Finally, the solution was injected into the UPLC system to measure the amino acid composition.

\subsection{Measurement of the Bacterial Growth Profile}

Bacterial (Escherichia coli and Staphylococcus aureus) growth media was made consisted of peptone extracted from the heads of catfish and pangas catfish (CP and PCP, respectively), commercial peptone (Merck), $\mathrm{NaCl}$, and yeast extract. The amounts of those components were equivalent to Luria Bertani (LB) broth medium. The treated growth media were sterilized in an autoclave at $121^{\circ} \mathrm{C}$ for $15 \mathrm{~min}$ at a pressure of 1 atm. The bacteria were cultured in $250 \mathrm{~mL}$ Erlenmeyer flasks containing $150 \mathrm{~mL}$ of different media in triplicate at $35^{\circ} \mathrm{C}$ in an incubator and shake at $150 \mathrm{rpm}$ (Andualem \& Gessesse, 2013). Bacterial growth measurement was done by measuring the cell concentrations (optical density (OD)) of $E$. coli and $S$. aureus in each medium at a wavelength of $600 \mathrm{~nm}$ by using a spectrophotometer (Shirahigue et al., 2018). 


\subsection{Measurement of Biomass Production}

The biomass test was carried out based on the method reported by Shirahigue et al. (2018) with a few modifications. A total of $25 \mathrm{~mL}$ of bacterial growth medium was incubated for $24 \mathrm{~h}$ in an incubator in a shaking mode at $150 \mathrm{rpm}$. The incubated cultures were centrifuged at $5,000 \mathrm{rpm}$ for $10 \mathrm{~min}$, followed by adding $0.85 \% \mathrm{NaCl}$ solution into the culture. Then, the cultures were recentrifuged in the same condition as described above. The bacterial precipitate was then dried at $105^{\circ} \mathrm{C}$ for $24 \mathrm{~h}$ in the oven.

\subsection{Statistical Analysis}

The experiments were conducted in triplicate, and the data were expressed as the mean values \pm standard deviation (SD). The differences were calculated using one-way analysis of variance (ANOVA) followed by Duncan's test. The significant difference was established at $P<0.05$ using SPSS, Version 25, statistical software program (SPSS Inc., Chicago, III., USA).

\section{Results and Discussion}

\subsection{Chemical Composition}

The moisture, protein, fat, and ash contents of raw materials and fish peptones extracted from the heads of catfish and pangas catfish are presented in Table 1. The fat component of pangas catfish was higher than the catfish; in contrast, the protein content in catfish heads was higher than the pangas catfish heads. This result suggested that pangas catfish have more lipids deposited in the head part compare to catfish. Previous studies have explored the proximate content of the head of tuna (Euthynnus affinis) that contains the protein $(19.30 \%)$, moisture $(68.79 \%)$, fat (7.01\%) and ash (4.77\%) (Khoddami et al., 2012). While in Pacific ocean perch (Sebastes alutus) contains protein (14.9\%), moisture (77.7\%), fat $(9.3 \%)$, and ash (6.7\%) (Bechtel et al., 2010). Based on the above findings, the protein content of catfish and pangas catfish heads were lower than tuna and Pacific Ocean perch. The different in chemical compositions of fish species are affected by species, sex, habitat, and season (Petricorena, 2014)

In a recent study, the peptones isolated from catfish (CFP) and pangas catfish (PCP) showed significant differences $(P<0.05)$ in protein and moisture contents, but no significant differences $(P>0.05)$ in fat and ash contents were observed. The protein components of both CFP and PCP were in the ranges of $84.35 \%$ to $89.41 \%$ and $87.31 \%$ to $90.8 \%$, respectively. The highest protein content was in PCP1 with a ratio of propionic acid:formic acid of $1: 2(\mathrm{v} / \mathrm{v})$, and the lowest protein content was in CFP3 (1:4, v/v of propionic

Table 1. Chemical composition of the head catfish peptone (CFP) and pangas catfish peptone (PCP)

\begin{tabular}{|c|c|c|c|c|c|}
\hline \multirow{2}{*}{\multicolumn{2}{|c|}{ Sample }} & \multicolumn{4}{|c|}{ Components } \\
\hline & & Moisture & Protein & Fat & Ash \\
\hline \multirow[t]{2}{*}{ By-products } & Catfish & $66.19 \pm 0.20$ & $13.43 \pm 0.25$ & $6.80 \pm 0.18$ & $6.80 \pm 0.15$ \\
\hline & Pangas & $63.80 \pm 0.21$ & $11.72 \pm 0.22$ & $14.26 \pm 0.23$ & $6.18 \pm 0.18$ \\
\hline \multirow[t]{6}{*}{ Peptones } & CFP1 & $3.39 \pm 0.31^{\mathrm{ab}}$ & $89.41 \pm 0.29^{a}$ & $0.51 \pm 0.19^{a}$ & $1.67 \pm 0.29^{a}$ \\
\hline & CFP2 & $4.14 \pm 0.28^{\mathrm{bc}}$ & $86.25 \pm 0.24^{b}$ & $0.47 \pm 0.13^{\mathrm{a}}$ & $1.64 \pm 0.33^{a}$ \\
\hline & CFP3 & $3.96 \pm 0.25^{\mathrm{a}}$ & $84.35 \pm 0.38^{d}$ & $0.42 \pm 0.11^{\mathrm{a}}$ & $1.94 \pm 0.25^{a}$ \\
\hline & PCP1 & $4.53 \pm 0.42^{\mathrm{a}}$ & $90.80 \pm 0.41^{c}$ & $0.65 \pm 0.13^{\mathrm{a}}$ & $1.55 \pm 0.14^{\mathrm{a}}$ \\
\hline & PCP2 & $4.63 \pm 0.30^{c}$ & $89.17 \pm 0.67^{d}$ & $0.68 \pm 0.18^{\mathrm{a}}$ & $1.82 \pm 0.21^{\mathrm{a}}$ \\
\hline & PCP3 & $3.52 \pm 0.34 b^{c}$ & $87.31 \pm 0.34^{e}$ & $0.58 \pm 0.15^{a}$ & $1.40 \pm 0.40^{\mathrm{a}}$ \\
\hline
\end{tabular}

Notes: Data are presented as the mean \pm standard deviation and different uppercase letters within the same column indicate significant differences $(P<0.05)$

CFP1: Catfish peptone extracted with $1.5 \%(\mathrm{v} / \mathrm{m})$ of propionic acid/formic acid $(1: 2, \mathrm{v} / \mathrm{v})$

CFP2: Catfish peptone extracted with $1.5 \%(\mathrm{v} / \mathrm{m})$ of propionic acid/formic acid $(1: 3, \mathrm{v} / \mathrm{v})$

CFP3: Catfish peptone extracted with $1.5 \%(\mathrm{v} / \mathrm{m})$ of propionic acid/formic acid $(1: 4, \mathrm{v} / \mathrm{v})$

PCP1: Pangas catfish peptone extracted with1.5\% $(\mathrm{v} / \mathrm{m})$ of propionic acid/formic acid $(1: 2, \mathrm{v} / \mathrm{v})$

PCP2: Pangas catfish peptone extracted with $1.5 \%(\mathrm{v} / \mathrm{m})$ of propionic acid/formic acid $(1: 3, \mathrm{v} / \mathrm{v})$ PCP3: Pangas catfish peptone extracted with1.5\% $(\mathrm{v} / \mathrm{m})$ of propionic acid/formic acid $(1: 4, \mathrm{v} / \mathrm{v})$ 
acid:formic acid). It might be due to the effect of the ratio of acid applied during hydrolysis to the protein content of fish head. The result also shows that the most effective ratio of propionic acid:formic acid used during the acid hydrolysis for peptone production is 1:2 (v/v). The result also revealed that the protein contents were in accordance to peptone produced by Merck (> 68.8\%) (Table 1). Moreover, protein is a major component of peptone, which is rich in nitrogen compounds as an essential nutrient in supporting microbial growth culture (Shirahigue et al., 2018). Some research studies have revealed that protein content was the major component of peptone. They reported that protein content in yellow stripes scad fish(Selaroides leptolepis) by-products, Atlantic cod (Gadus morhua) stomach, tuna (Thunnus sp.) viscera, silver carp (Hypophthalmichthys molitrix) (filleting byproducts), herring (Clupea harengus) and mackerel (Scomber japonicus) by-products, were $83.62 \%$, $75.4 \% ; 50.18 \%, 91.53 \%, 90.7 \%$ and $84.7 \%$, respectively (Saputra and Nurhayati et al., 2013; Fallah et al., 2015; Gildberg et al., 2010). The moisture, fat, and ash components of the CFP and PCP of the extracted peptone samples were $3.39 \%$ to $4.63 \%$, $0.42 \%$ to $0.68 \%$, and $1.40 \%$ to $1.94 \%$, respectively. Theoretically, when protein content increases, other components decrease. The ash contents of all peptone samples were in accordance with the standard of bacterial peptone from Merck ( $<17 \%)$.

\subsection{Yield and Solubility of CFP and PFP Products}

The yield and solubility of peptone extracted from the heads of catfish and pangas catfish with different acid combinations were observed, and the results are presented in Table 2. In general, for the yield parameter, the peptone samples were significantly different $(P<0.05)$ and ranged between $4.75 \%$ and $5.66 \%$. The extracted peptone from catfish head showed higher yield compared with pangas catfish. It can be suggested that the protein contained in the catfish sample was higher than that in the pangas catfish sample. Thus acid-assisted extraction with different combinations could result in higher yield. These results were in line with the peptone of grouper head (Epinephelus fuscoguttatus) yielded between $4.31 \%$ and $5.70 \%$ extracted by acid solution. In addition, the yields also were in accordance to other studies conducted by enzyme-assisted extraction on the peptone of yellow stripe scad fish (S. leptolepis) $(5.23 \%)$ and tuna (Thunnus sp.) viscera (5.54\%), respectively, (Saputra and Nurhayati, 2013; Nurhayati et al., 2013). The reason might be that acid-assisted extraction can generate peptide bonds in nonspecific cleavage site. Moreover, the acid condition can support the autolysis process, which allows endogenous enzymes to break down the protein substrates into soluble products, resulting in a complex mixture of peptides and amino acids. This acid extraction provides good separation between aqueous soluble and an oil-rich fraction that effects on the yielded product (Gildberg et al., 2010).

Solubility is an important physical property of peptone since peptone is a soluble protein that is uncoagulated at high temperatures (Khalil, 2012). Table 2 is shown that the solubility of the peptone samples ranged between $98.03 \%$ and $99.52 \%$. The

Table 2. Yield and solubility of the catfish peptone (CFP) and pangas catfish peptone (PCP) from fish heads

\begin{tabular}{ccc}
\hline Sample & Yield & Solubility (\%) \\
\hline CFP1 & $5.66 \pm 0.02^{\mathrm{d}}$ & $98.37 \pm 0.15^{\mathrm{a}}$ \\
CFP2 & $5.25 \pm 0.05^{\mathrm{c}}$ & $98.17 \pm 0.30^{\mathrm{a}}$ \\
CFP3 & $5.24 \pm 0.06^{\mathrm{c}}$ & $98.03 \pm 0.23^{\mathrm{a}}$ \\
PCP1 & $4.98 \pm 0.03^{\mathrm{b}}$ & $99.52 \pm 0.29^{\mathrm{b}}$ \\
PCP2 & $4.81 \pm 0.09^{\mathrm{ab}}$ & $99.40 \pm 0.27^{\mathrm{b}}$ \\
PCP3 & $4.75 \pm 0.14^{\mathrm{a}}$ & $99.28 \pm 0.29^{\mathrm{b}}$ \\
\hline
\end{tabular}

Notes: Data are presented as the mean \pm standard deviation and different uppercase letters within the same column indicate significant differences $(P<0.05)$

CFP1: Catfish peptone extracted with $1.5 \%(\mathrm{v} / \mathrm{m})$ of propionic acid/formic acid $(1: 2, \mathrm{v} / \mathrm{v})$

CFP2: Catfish peptone extracted with $1.5 \%(\mathrm{v} / \mathrm{m})$ of propionic acid/formic acid $(1: 3, \mathrm{v} / \mathrm{v})$

CFP3: Catfish peptone extracted with $1.5 \%(\mathrm{v} / \mathrm{m})$ of propionic acid/formic acid $(1: 4, \mathrm{v} / \mathrm{v})$

PCP1: Pangas catfish peptone extracted with $1.5 \%(\mathrm{v} / \mathrm{m})$ of propionic acid/formic acid $(1: 2, \mathrm{v} / \mathrm{v})$

PCP2: Pangas catfish peptone extracted with $1.5 \%(\mathrm{v} / \mathrm{m})$ of propionic acid/formic acid $(1: 3, \mathrm{v} / \mathrm{v})$

PCP3: Pangas catfish peptone extracted with $1.5 \%(\mathrm{v} / \mathrm{m})$ of propionic acid/formic acid $(1: 4, \mathrm{v} / \mathrm{v})$ 
solubility of the CFP and PCP samples was following the solubility of the peptone extracted from yellow stripe scad fish (S. leptolepis) reported by Saputra and Nurhayati (2013). The solubility of the peptone samples is due to the presence of a hydroxy group in the peptone that interacts with water molecules. Other factors affecting the solubility are the raw material used to produce peptone (species, freshness and parts), hydrolysis method, pH value, and a time period during the hydrolysis process (Marmon, 2012). Furthermore, the high solubility value in protein hydrolysate is caused by the reaction of protein breakdown into simpler peptides (Barokah et al., 2017).

\subsection{Color Analysis}

The color parameters of peptone samples extracted from catfish and pangas catfish head by-products under different acid conditions are presented in Table 3 and captured in Figure 1. The data represented by the color parameters are $L^{*}$ (lightness), $a^{*}$ (redness), $b^{*}$ (yellowness), color intensity, and whiteness.
Generally, the CFP and PCP samples had significantly different $(\mathrm{P}<0.05)$ color parameters. The $L^{*}, a^{*}, b^{*}$, intensity and whiteness values of the peptone samples were in the range of $83.30 \%$ to $87.65 \%,-0.90 \%$ to $0.34 \%, 25.24 \%$ to $32.55 \%, 64.13 \%$ to $70.39 \%$, and $32.47 \%$ to $40.67 \%$, respectively. The highest $L^{*}$-values of the peptone samples were shown in PCP1 with formic acid at low concentration. The results were also in line with the whiteness value of the peptone samples. However, the color intensity was lower than the catfish head peptone obtained with a high concentration of formic acid. This result suggested that peptone samples extracted with acid solutions give more whiteness in the color of the peptone product. Acid-assisted extraction (particularly formic acid) can form a great separation between aqueous soluble and oil-rich phase, and this lipid content can influences degree of whiteness in the hydrolyzed products (Gildberg et al., 2010). Moreover, the color parameters of peptone are affected by the raw materials used and the extraction method (Klompong et al., 2009).

Table 3. Color parameter of the catfish head peptone (CFP) and pangas catfish head peptone (PCP)

\begin{tabular}{cccccc}
\hline Sample & $\mathbf{L}^{*}$ & $\mathbf{a}^{*}$ & $\mathbf{b}^{*}$ & Color intensity & Whiteness \\
\hline CFP1 & $84.33 \pm 0.16^{\mathrm{b}}$ & $-0.64 \pm 0.05^{\mathrm{b}}$ & $25.77 \pm 0.14^{\mathrm{b}}$ & $69.63 \pm 0.15^{\mathrm{d}}$ & $39.53 \pm 0.13^{\mathrm{d}}$ \\
CFP2 & $83.30 \pm 0.20^{\mathrm{a}}$ & $-0.68 \pm 0.07^{\mathrm{b}}$ & $25.72 \pm 0.23^{\mathrm{b}}$ & $68.60 \pm 0.18^{\mathrm{c}}$ & $37.45 \pm 0.14^{\mathrm{c}}$ \\
CFP3 & $83.81 \pm 0.19^{\mathrm{ab}}$ & $-0.90 \pm 0.01^{\mathrm{a}}$ & $25.24 \pm 0.18^{\mathrm{a}}$ & $70.39 \pm 0.16^{\mathrm{e}}$ & $40.29 \pm 0.13^{\mathrm{e}}$ \\
PCP1 & $87.65 \pm 0.23^{\mathrm{d}}$ & $-0.53 \pm 0.06^{\mathrm{c}}$ & $28.74 \pm 0.23^{\mathrm{c}}$ & $68.78 \pm 0.13^{\mathrm{c}}$ & $40.67 \pm 0.21^{\mathrm{f}}$ \\
PCP2 & $84.73 \pm 0.05^{\mathrm{c}}$ & $-0.64 \pm 0.10^{\mathrm{b}}$ & $30.12 \pm 0.20^{\mathrm{d}}$ & $66.49 \pm 0.10^{\mathrm{b}}$ & $35.55 \pm 0.06^{\mathrm{b}}$ \\
PCP3 & $84.74 \pm 0.65^{\mathrm{c}}$ & $-0.34 \pm 0.06^{\mathrm{d}}$ & $32.55 \pm 0.16^{\mathrm{e}}$ & $64.13 \pm 0.09^{\mathrm{a}}$ & $32.47 \pm 0.15^{\mathrm{a}}$ \\
\hline
\end{tabular}

Notes: Data are presented as the mean \pm standard deviation and different uppercase letters within the same column indicate significant differences $(P<0.05)$

CFP1: Catfish peptone extracted with $1.5 \%(\mathrm{v} / \mathrm{m})$ of propionic acid/formic acid $(1: 2, \mathrm{v} / \mathrm{v})$

CFP2: Catfish peptone extracted with1.5\% $(\mathrm{v} / \mathrm{m})$ of propionic acid/formic acid $(1: 3, \mathrm{v} / \mathrm{v})$

CFP3: Catfish peptone extracted with $1.5 \%(\mathrm{v} / \mathrm{m})$ of propionic acid/formic acid $(1: 4, \mathrm{v} / \mathrm{v})$

PCP1: Pangas catfish peptone extracted with $1.5 \%(\mathrm{v} / \mathrm{m})$ of propionic acid/formic acid $(1: 2, \mathrm{v} / \mathrm{v})$

PCP2: Pangas catfish peptone extracted with $1.5 \%(\mathrm{v} / \mathrm{m})$ of propionic acid/formic acid $(1: 3, \mathrm{v} / \mathrm{v})$

PCP3: Pangas catfish peptone extracted with $1.5 \%(\mathrm{v} / \mathrm{m})$ of propionic acid/formic acid $(1: 4, \mathrm{v} / \mathrm{v})$

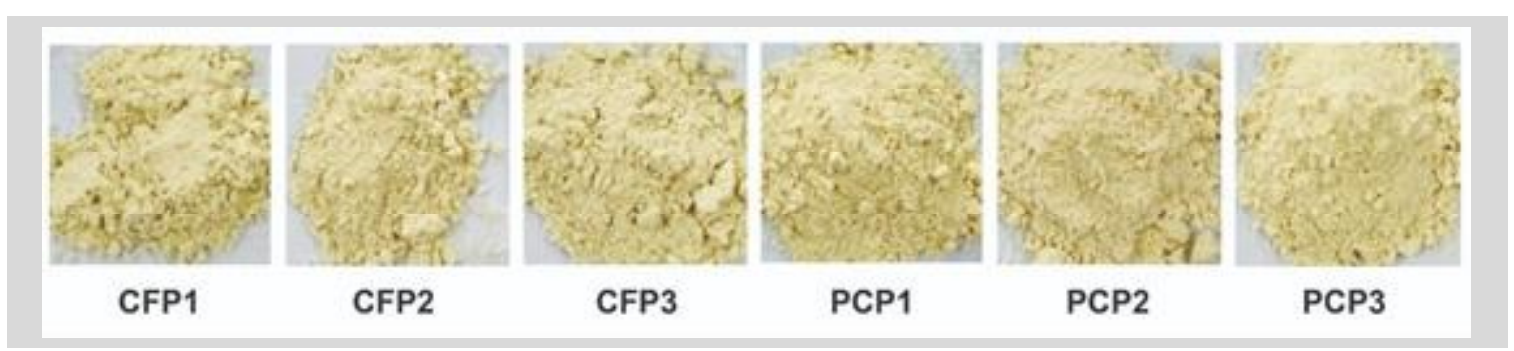

Note: Catfish head peptone (CFP); Pangas catfish head peptone (PCP)

Figure 1. CFP and PCP samples extracted under different acid conditions 
Some research studies have reported that peptone extracted from marine fish by-products (multi-species) had $L^{*}, a^{*}, b^{*}$, and whiteness values were $52.64 \%$, $2.50 \%, 7.99 \%$ and $51.44 \%$, respectively (Nurhayati et al., 2015). Barokah et al. (2017) observed that microencapsulated peptone from marine by-products multi-species of mackerel (S. japonicus), yellow stripe scad (S. leptolepis), round scad (Decapterus punctatus), white sardinella (Sardinella albella), large head hair tail (Trichiurus lepturus), and cowtail rays ( $T$. sephen) produced $L^{*}, a^{*}, b^{*}$, and whiteness values of $60.01 \%, 1.70 \%, 10.33 \%$ and $57.44 \%$, respectively. CFP and PCP lightness and whiteness value were higher compared to the above findings. However, the lightness value of extracted peptone in this recent study was lower than that reported by Klompong et al. (2009), who reported that yellow stripe trevally samples had a lightness $\left(L^{*}\right)$ value of approximately $84.90 \%$.

\subsection{Amino Acid Composition}

The composition of amino acids in the peptone samples extracted from the heads of catfish and pangas catfish was determined, and the data are tabulated in Table 4. In both CFP and PCP samples, the amino acid with the highest values was glycine, followed by glutamic acid, proline and leucine, at the same time the contents of tyrosine, histidine and isoleucine were low. Moreover, both CFP and PCP samples had higher total amino acid compositions compared to the commercial peptone (Merck). These results were similar with peptones extracted from the by-products of marine fish species, including those reported from bolti fish (O. niloticus) (Khalil, 2012), Atlantic cod fish (G. morhua) (Gildberg et al., 2010) and cowtail rays ( $T$. sephen) (Poernomo and Buckle, 2002). The value of glycine in the PCP samples was varied between 16.38 and $19.05 \mathrm{~g} / 100 \mathrm{~g}$, while, tyrosine which had the lowest amino acid value, ranging from 0.87 to $1.27 \mathrm{~g} / 100 \mathrm{~g}$.

Furthermore, the essential amino acids of the CFP and PCP peptone samples were detected; the major composition was proline, and the minor composition was histidine, representing ranges of 7.89 to 10.29 and 0.93 to 1.62 , respectively. The amino acid composition of peptone samples isolated from catfish and pangas catfish heads in this study indicates that peptone is an essential substrate for the growth of microorganisms. Aspmo et al. (2005) reported that supplementation of leucine, valine and isoleucine in microbial growth medium could support the growth rate under culture conditions. Also, Shirahigue et al. (2018) revealed that the amino acids contained in peptone were able to increase the growth performance of microorganisms.

Table 4. Amino acid composition of the catfish head peptone (CFP) and pangas catfish head peptone (PCP)

\begin{tabular}{|c|c|c|c|c|c|c|c|}
\hline Amino acids & CFP1 & CFP2 & CFP3 & PCP1 & PCP2 & PCP3 & $\mathrm{CP}^{\star *}$ \\
\hline Arginine ${ }^{*}$ & $5.32 \pm 0.20$ & $5.00 \pm 0.14$ & $5.41 \pm 0.13$ & $5.86 \pm 0.14$ & $5.93 \pm 0.21$ & $4.85 \pm 0.13$ & 3.8 \\
\hline Alanine & $4.72 \pm 0.15$ & $5.37 \pm 0.01$ & $4.58 \pm 0.08$ & $5.79 \pm 0.24$ & $5.66 \pm 0.16$ & $5.89 \pm 0.12$ & 5.4 \\
\hline Aspartic acid & $7.97 \pm 0.16$ & $8.30 \pm 0.17$ & $7.42 \pm 0.07$ & $5.47 \pm 0.09$ & $5.80 \pm 0.011$ & $6.28 \pm 0.08$ & 7.5 \\
\hline Glutamic acid & $12.83 \pm 0.12$ & $11.91 \pm 0.13$ & $12.19 \pm 0.10$ & $10.05 \pm 0.14$ & $10.60 \pm 0.10$ & $12.83 \pm 0.25$ & 9.6 \\
\hline Glycine & $18.17 \pm 0.27$ & $18.09 \pm 0.12$ & $18.66 \pm 0.09$ & $19.05 \pm 0.16$ & $18.22 \pm 0.19$ & $16.38 \pm 0.14$ & 7.4 \\
\hline Histidine* & $1.58 \pm 0.10$ & $1.56 \pm 0.17$ & $1.62 \pm 0.14$ & $1.30 \pm 0.09$ & $1.36 \pm 0.25$ & $0.93 \pm 0.12$ & 1.9 \\
\hline Isoleucine* & $4.77 \pm 0.11$ & $5.23 \pm 0.18$ & $4.99 \pm 0.12$ & $4.91 \pm 0.17$ & $4.97 \pm 0.07$ & $4.86 \pm 0.19$ & 3 \\
\hline Leucine* & $8.45 \pm 0.27$ & $9.28 \pm 0.32$ & $8.82 \pm 0.18$ & $8.57 \pm 0.21$ & $8.74 \pm 0.21$ & $8.51 \pm 0.23$ & 6 \\
\hline Lysine ${ }^{*}$ & $5.69 \pm 0.25$ & $5.89 \pm 0.16$ & $5.50 \pm 0.17$ & $5.46 \pm 0.13$ & $6.08 \pm 0.20$ & $8.31 \pm 0.13$ & 7 \\
\hline Phenylalanine* & $4.87 \pm 0.21$ & $5.26 \pm 0.07$ & $4.90 \pm 0.15$ & $4.73 \pm 0.17$ & $5.25 \pm 0.32$ & $3.47 \pm 0.12$ & 3.7 \\
\hline Proline* & $9.37 \pm 0.19$ & $8.15 \pm 0.16$ & $9.36 \pm 0.13$ & $10.29_{ \pm} 0.07$ & $7.89 \pm 0.11$ & $10.21 \pm 0.19$ & 4.3 \\
\hline Serine & $3.94 \pm 0.11$ & $3.79 \pm 0.15$ & $4.10 \pm 0.09$ & $4.77 \pm 0.10$ & $5.28 \pm 0.14$ & $4.62 \pm 0.16$ & 3 \\
\hline Threonine* & $4.78 \pm 0.09$ & $4.12 \pm 0.09$ & $4.80 \pm 0.16$ & $5.91 \pm 0.15$ & $6.07 \pm 0.10$ & $5.15 \pm 0.13$ & 3 \\
\hline Tyrosine & $1.04 \pm 0.21$ & $1.03 \pm 0.13$ & $1.04 \pm 0.14$ & $1.01 \pm 0.05$ & $1.27 \pm 0.19$ & $0.87 \pm 0.17$ & 1.2 \\
\hline Valine* & $6.54 \pm 0.25$ & $7.01 \pm 0.21$ & $6.63 \pm 0.16$ & $6.84 \pm 0.21$ & $6.88 \pm 0.24$ & $6.83 \pm 0.18$ & 4.8 \\
\hline
\end{tabular}

Note: * Essential amino acids (EAAs), ${ }^{\star \star} \mathrm{CP}$ : Commercial meat-based peptone (Merck, 2010) 


\subsection{Bacterial Growth Profile}

The successful peptone product was evaluated with the growth of the selected microorganisms (Vieira et al., 2005). A spectrophotometer was used to measure the growth of selected bacteria, such as $S$. aureus and $E$. coli, based on the optical density at a wavelength of $600 \mathrm{~nm}$. The bacterial growth curves in media supplemented with peptone extracted from the heads of catfish and pangas catfish are depicted in Figure 2.

The growth performance of $S$. aureus and $E$. coli in LB broth medium supplemented with peptone isolated from catfish and pangas catfish heads compared to commercial peptone was significantly different $(P<0.05)$. The superior growth performance of $S$. aureus and E. coli was observed in CFP1 and PCP1, followed by CFP2 and PCP2, CFP3 and PCP3, and commercial peptone. The trend of bacterial growth curves was typically similar to each growth profile in each medium supplemented with peptone from catfish and pangas catfish heads. It can be suggested that the effective acid combination applied

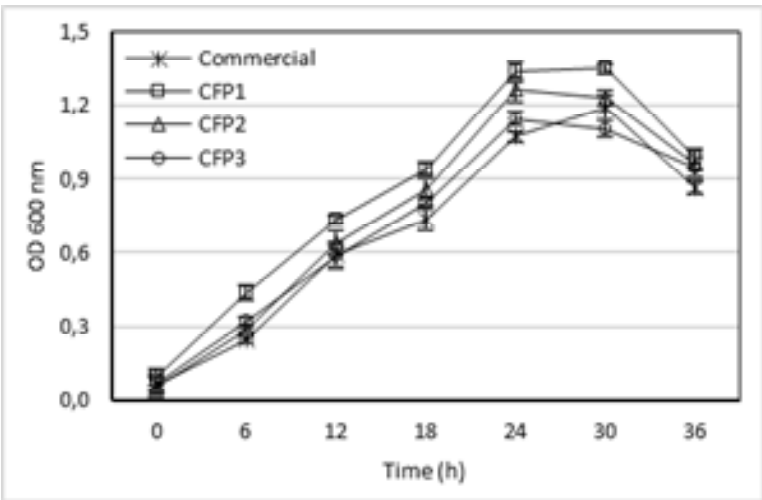

(a)

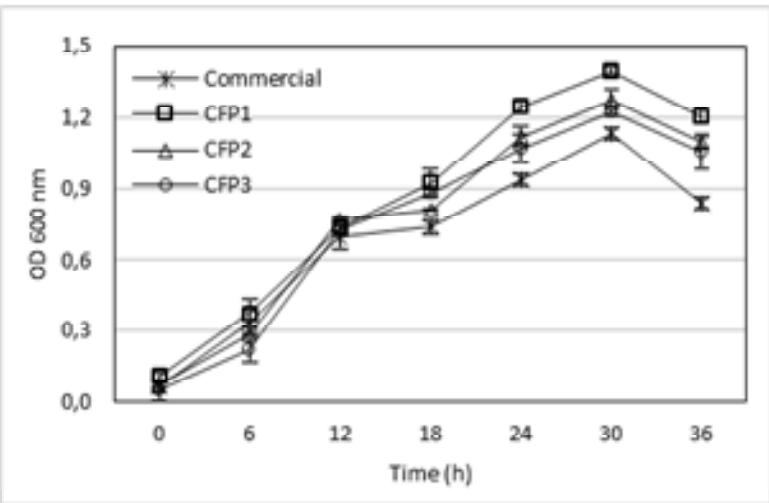

(c) during hydrolysis is in the ratio of propionic:formic acids of $1: 2(\mathrm{v} / \mathrm{v})$. This means that a low concentration of propionic acid combined with formic acid had a significant effect on the bacterial growth profiles. These findings are also consistent with the protein content of peptone samples used in this study because high protein content in peptone will give a high nitrogen content. Zhao and Shimizu (2003) concluded that $E$. coliutilizes nitrogen compounds derived from glutamic acid for its growth, while $S$. aureus requires tyrosine substances (Harris et al., 2002). Several studies have explored whether peptones extracted from different fish species, such as cod, salmon, tuna, and unspecified fish, showed a higher microbial growth rate than casein peptone (Dufossé et al., 2001). Moreover, peptones isolated from different fish species exhibited better bacterial growth profiles than commercial peptones (Vieira et al., 2005 and Safari et al., 2011). These findings were following with those reported by Klompong et al. (2009), Saputra et al. (2020), and Husin et al. (2015). It can be concluded that peptone extracted from fish by-products is able to support microbial growth performance.

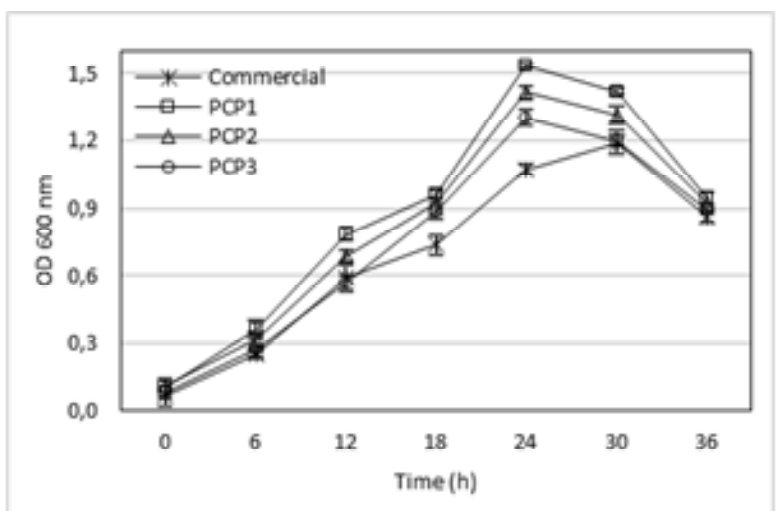

(b)

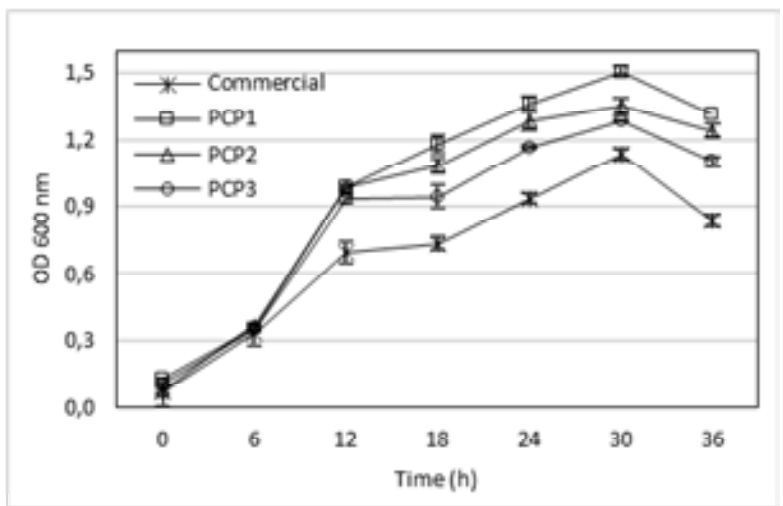

(d)

Note: (a) S. aureus in LB broth supplemented with CFP; (b) S. aureus in LB broth supplemented with PCP; (c) E. coli in LB broth supplemented with CFP; (d) E. coli in LB broth supplemented with PCP

Figure 2. Bacterial growth profile supplemented with the heads of catfish and pangas catfish peptone 


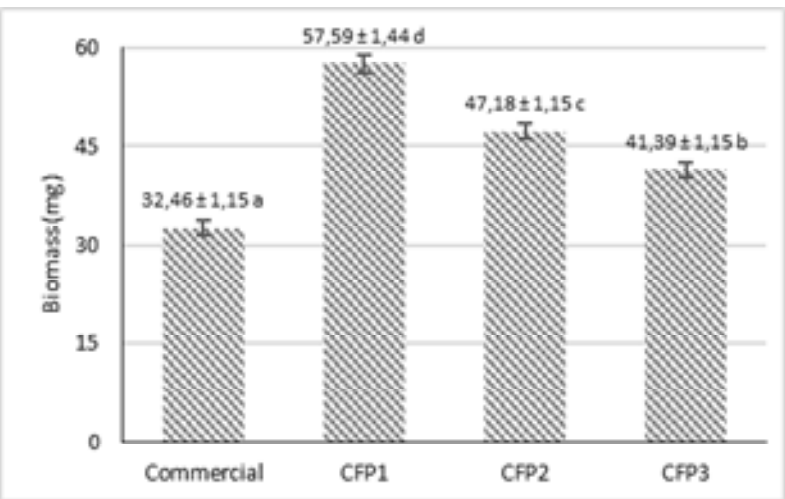

(a)

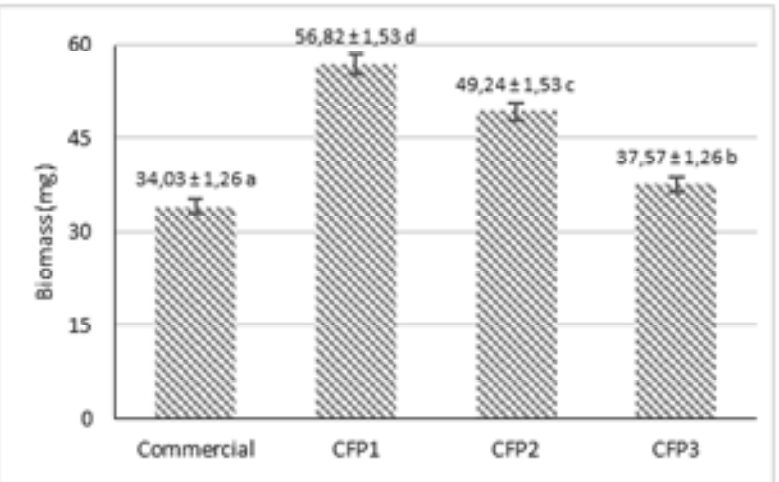

(c)

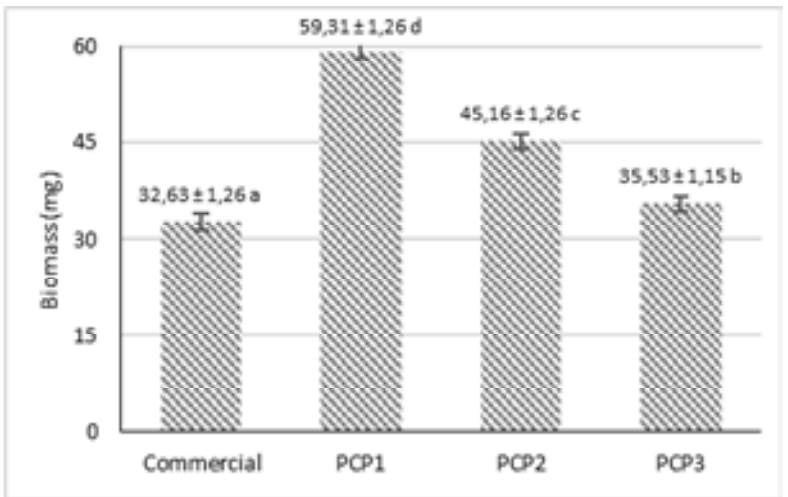

(b)

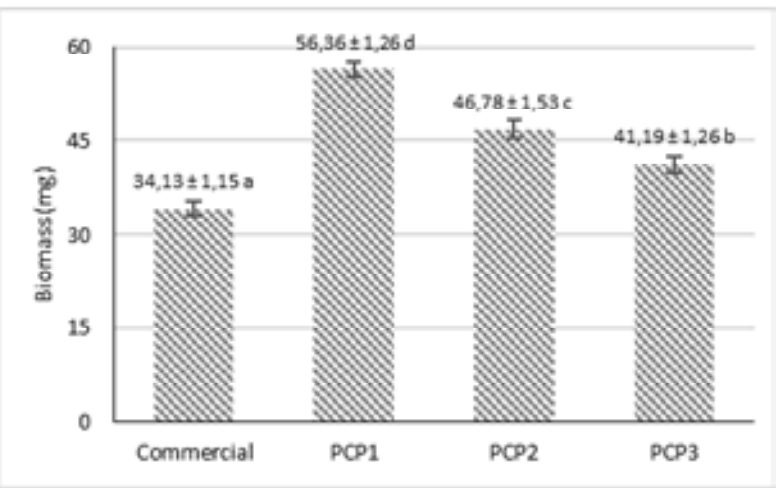

(d)

Note: (a) S. aureus culture in media containing CFP; (b) S. aureus culture in media containing PCP; (c) E. coli culture in media containing CFP; (d) E. coli culture in media containing PCP

Figure 3. Biomass production $(\mathrm{mg} / 100 \mathrm{~mL})$ in LB broth media supplemented with peptone

\subsection{Biomass Production}

The bacterial biomass production of two selected bacteria ( $S$. aureus and $E$. coli) in LB broth media supplemented with peptone hydrolyzed under different acid conditions from catfish and pangas catfish heads was measured according to Shirahigue et al. (2018), and the yielded biomass is depicted in Figure 3 . The production of $S$. aureus and $E$. colibiomass in different media supplemented with commercial peptone and treated peptones (both CFP and PCP with different acid combinations) was significantly different $(P<0.05)$. The yielded biomass ranged from 41.39 to $57.59,35.53$ to $59.31,37.57$ to 56.82 and 41.19 to 56.36 (in $\mathrm{mg}$ per $100 \mathrm{~mL}$ ) for CFP with $S$. aureus, PCP with $S$. aureus, CFP with E. coli, and PCP with E. coli, respectively. In general, the biomass production profiles observed in this study had similar trends. When compared to commercial peptone supplementation in the bacterial culture, both CFP and PCP showed higher biomass yields in either $S$. aureus or $E$. coli cultures. In addition, the highest biomass production was observed in a medium containing peptone hydrolyzed with an acid combination of propionic and formic acid in the ratio of $1: 2(\mathrm{v} / \mathrm{v})$. It can be suggested that peptone extracted from catfish and pangas catfish heads with a combination of propionic and formic acids in the ratio of $1: 2(\mathrm{v} / \mathrm{v})$ showed effective biomass production. The treated peptones used in the recent study have higher biomass yield compared to commercial peptone. Poernomo and Buckle (2002) revealed that high biomass production provides adequate nutrients to support the growth rate of microorganisms.

Furthermore, the higher the biomass production gained, the more effective the growth rate of microorganisms. These findings are in line with other studies reporting that peptones produced from different fish wastes, including Panulirus argus, Panulirus laevicauda, and Macrobrachium amazonicum, showed a significant biomass production for Escherichia coli compared to commercial peptone (Saputra and Nurhayati, 2013). Moreover, Poernomo and Buckle (2002) and Shirahigue et al. (2018) reported that a higher biomass production for five microorganisms in cowtail ray $(P$. sephen) peptones and two bacteria (E. coli and $S$. aureus) in both tilapia (O.niloticus) and cobia ( $R$. canadum) peptones, respectively. 


\section{Conclusion}

Peptones from the heads of catfish (CFP) and pangas catfish (PCP) could be extracted with the aid of acid solution. Under different acid conditions, both CFP and PCP showed high protein content with low lipid content. The solubility of the treated peptones varied between $98.03 \%$ and $99.52 \%$, and the peptones were rich in glycine, glutamic acid, proline and leucine. The bacterial growth test showed that both CFP and PCP exhibited better growth rates compared to the commercial peptone tested in this study. In addition, biomass production was higher in catfish and pangas catfish peptone than the commercial products. This finding indicated that peptones extracted from catfish and pangas catfish heads could be promising alternative sources for peptone production.

\section{Acknowledgment}

We would like to thank the Directorate of Research and Community Service, Ministry of Research, Technology and Higher Education of the Republic of Indonesia for financial support (DRPM Fund 2019-2020/ No. 330.30/UN10.C10/PN/2019).

\section{References}

Andualem, B. \& A. Gessesse. (2013). Production of microbial medium from defatted breba (Milletia ferruginea) seed flour to substitute commercial peptone agar. Asian Pacific Journal of Tropical Biomedicine, 3(10), 790-797. doi: 10.1016/S22211691(13)60157-4

AOAC. 2000. Official methods of analysis (17th Edn). Association of Official Analytical Chemist, Washington. D.C.

Aspmo, S. I., Horn, S. J., \& Eijsink,V. G. H. (2005). Hydrolysates from Atlantic cod (Gadus morhue L.) viscera as components of microbial growth media. Process Biochemistry. 40, 3714-3722.

Barokah, G. R. B., Ibrahim., \& Nurhayati. (2017). Characterization of microencapsul peptone from spoiled by catch fish using spray drying methods. Indonesian Fisheries Processing Journal.20(2), 401412. (in Indonesia). doi: http://dx.doi.org/10.17844/ jphpi.v20i2.18108.

Bechtel, P., Morey, A., Oliveira., \& Alexandra, W. (2010). Chemical and nutritional properties of Pacific Ocean perch (Sebastes alutus) whole fish and by-products. Journal of Food Processing \& Preservation. 34, 55 72.https://doi.org/10.1111/j.1745-4549.2008.00279.x

Benites, D. C. ,Verboven, Y., Stroman, D., \& Kodjikian, L. (2011). The role of topical moxifloxacin, a new antibacterial in Europe, in the treatment of bacterial conjunctivitis. Clinical Drug Investigation 31(8), 543570.doi: 10.2165/11589020-000000000-00000.

Deraz, S. F., El-Fawal, G. F., Abd-Ellatif, S. A., \& Khalil, A. A. (2011). Autohydrolysed Tilapia nilotica fish viscera as a peptone source in bacteriocin production. Indian Journal of Microbiology. 51(2), 171-175.doi: 10.1007/ s12088-011-0119-0

Dufossé, L., Broise, D. L. B., \& Guerard, F. (2001). Evaluation of nitrogenous substrates such as peptones from fish: A new methode on gompertz modeling of microbial growth. Current Microbiology. 42, 32-39.doi: 10.1007/s002840010174

Fallah, M., Bahram, S., \& Javadian, S. R. (2015). Fish peptone development using enzymatic hydrolysis of silver carp by-products as a nitrogen source in Staphylococcus aureus media. Food Science \& Nutrition. 3 (2), 153-157.doi: 10.1002/fsn3.198.

FAO. (2018).www.fao.org. Accessed Nov 9, 2019.

Gildberg, A., Dahl, R., Milkkelsen, H., \& Nilsen, K. (2010). Peptons from Atlantic cod stomach as nitrogen sources in growth media to marine bacteria. Journal of Aquatic Food Product Technology. 19, 75-83.doi: 10.1080/10498850.2010.486523.

Global Peptone Market Report. (2019). Marketwatch.com. Published Oct 10, 2019. Accessed Nov 10, 2019.

Harris, L. G., Foster, S. J., \& Richards, R. G. (2002). An introduction to Staphylococcus aureus \& techniques for identifying and quantifying Staphylococcus aureus adhesins relation to adhesion to biomaterials. Journal European Cells and Materials. 4, 39-60.doi: 10.22203/eCM.v004a04

Herpandi., Huda, N., \& Adzitey, F. (2011). Fish bone and scale as a potential source of halal gelatin. Journal of Fisheries and Aquatic Science. 6(4), 379-389.doi: 10.3923/jfas.2011.379.389

Husin, N., Mazlina, S., Kamal, M., Chuan, L.T., Muhammad, N.F.,\& Jusoh, N. (2015). Comparison of microbial growth on fish waste peptones from different hydrolysis methods. 5th International Conference on Biomedical Engineering \& Technology (ICBET 2015). IACSIT Press, Singapore, 54-57.doi: 10.7763/IPCBEE.2015.

Jaziri, A. A., Setijawati, D., Yufidasari, H. S., Pratomo, M. D., Wardani, D. W., Ersyah, D., \& Huda, N. (2020). Characteristics of peptones from grouper (Epinephelus fuscoguttatus) and parrotfish (Scarus javanicus) heads by-products as bacterial culture media. Journal of Biotech Research, 11: 1-12.

Khalil, A. A. (2012). Protein characterization of the aqueous soluble phase of acidified and autolyzed bolti fish (Tilapia nilotica) viscera. Asian Journal of Biotechnology. 4(3), 108-119.doi: 10.3923/ajbkr. 2012.108.119.

Khoddami, A., Arifin, A. A., Bakar, J., \& Ghazali, H. M. (2012). Quality and fatty acid profile of the oil extracted from fish waste (head, intestine and liver) (Euthynnusaffinis). African Journal of Biotechnology. 11 (7), 1683-1689.doi:10.5897/AJB10.1699

Klompong, V., Benjakul, S., Kantachtoe, D., \& Shahidi, F. (2009). Characteristics and use of yellow stripe trevally hydrolysate as culture media. Journal of Food Science. 74(6), 219-225.doi: 10.1111/j.17503841.2009.01213.x 
Marmon, S. (2012). Protein isolation from Herring (Clupea harengus) using the $\mathrm{pH}$-shift process. Thesis. Chalmers University of Technology. Sweden. Merck. 2010. Microbiology Manual $12^{\text {th }}$ Edition, Germany

Ministry of Marine \& Fisheries Affairs. (2017). https:// kkp.go.id/, Accessed Nov 9, 2019.

Ministry of Marine \& Fisheries Affairs. (2018). https:// kkp.go.id/, Accessed Nov 9, 2019.

Najim, S. M., Al-Noor, J. M., \& Al-Waely, W. A. (2015). Extraction of crude peptone from fish wastes for use as a nitrogen source in microbiological media. Global Journal of Fisheries and Aquaculture Researches. 2, 29-37.

Ningsih, R., Sudarno., \& Agustono. (2018). The effect of maltodextrin concentration on characteristic of peptone fish capacity (Lutjanus sp.).Agrointek. 12(1), 55-60. (in Indonesia)

Ningsih, S. G., Jacoeb., Agoes, M., Poernomo., \& Djoko. (2011). Fatty acid analysis and observation of fillet pangas fish tissue (Pangasius hypophthalmus) due to frying process. Thesis. IPB. (in Indonesia)

Nollet, L. M. L., \& Fidel, T. (2015). Hand book of Food Analysis. Two Volume Set. Boca Raton. CRC Press.

Nurhayati, T., Desniar \& M. Suhandana. (2013). Enzymatically produced peptone using baby tuna viscera. Indonesian Fisheries Processing Journal. 16(1), 1-11. (in Indonesia)

Nurhayati, T., Ibrahim, B., Suptijah, P., Salamah, E., Fitra, R. N., \&Astuti, E. R. W. (2015). Characterization of peptone from spilled by-catch fish as nutrient source for growth of bacteria and yeast. Indonesian Fisheries Processing Journal. 25 (1), 68-77. (in Indonesia)

Petricorena, Z. C. (2014). Chemical composition of fish and fishery products. Handbook of Food Chemistry. Springer Berlin Heidelberg. p.1-28.

Poernomo, A \& Buckle, K. A. (2002). Crude peptone from cowtail ray (Trygon sephen) viscera as microbial growth media. World Journal Microbiology Biotechnology. 18:333-340.doi:10.1023/A:101520 8519709.

Safari, R., Saravi, H.N., Pourgholam, R., Motalebi, A. A., \&Ghoroghi, A. (2011). Use of hydrolysates from silver carp (Hypophthalmichthys molitrix) head as peptone for Vibrio anguillarum and optimization using response surface method (RSM). Journal of Aquatic
Food Production Technology.20(2), 247- 257.https:/ /doi.org/10.1080/10498850.2011.562064

Saputra, D., \& Nurhayati, T. (2013). Application and production of yellow stripe scad fish peptone for bacteria's growth media. Indonesian Fisheries Processing Journal. 16(3), 215-223. (in Indonesia)

Saputra, D., Nurhayati, T., \& Purwaningsih, S. (2020). End post-rigour phase yellow stripe scad fish (Caranx leptolepis) peptones and its application for bacteria's growth media. Food Research. 4(2), 413420.doi: 10.26656/fr.2017.4(2).210

See, S. F., Hoo, L. L., \& Babji, A. S. (2011). Optimization of enzymatic hydrolysis of salmon (Salmo salar) skin by alcalase. International Food Research Journal. 18, 1359-1365.

Setijawati, D., Jaziri, A. A., Yufidasari, H. S., Wardani, D. W., Pratomo, M. D., Ersyah, D., \& Huda, N. (2019). Characteristics of peptone from the mackerel, Scomber japonicus head by-product as bacterial growth media. Bioscience Biotechnology Research Communications.12(4), 829-836.

Shirahigue, L. D., Ribeiro, I. S., Sucasas, L. F. A., Anbe, L., Vaz-Pires, P., \& Oetterer, M. (2018). Peptones in silage from tilapia (Oreochromis niloticus) and Cobia (Rachycentron canadum) waste as a culture medium for bioprocesses. Journal of Aquatic Food Product Technology. 27(6), 712-721.doi:10.1080/ 10498850.2018.1484830.

Srikandace, Y., Priatni, S., Pudjiraharti, S., Kosasih, W., \& L, Indrarti. (2017). Kerong fish (Terapon jarbua) peptone production using papain enzyme as nitrogen source in bacterial media. Journal of Physics: Conference Series. 1-5.doi: 10.1088/1755-1315/60/ $1 / 012005$

Statistics Indonesia. (2014). Statistics Bulletin Foreign Trade. https://www.bps.go.id. Accessed Nov 9, 2019. (in Indonesia)

Vieira, G. H., Vieira, R. H., Macrae, A., \& Sousa, O. V. (2005). Peptone preparation from ûshing byproducts. Journal of the Science of Food and Agriculture. 85, 1235-1237.https://doi.org/10.1002/ jsfa.2161

Zhao, J., \& Shimizu, K. (2003). Metabolic flux analysis of Escherichia coli $\mathrm{K} 12$ grown on C-labeled acetate and glucose using GC-MS \& powerful flux calculation method. Journal of Biotechnology. 101, 101-117.doi: 10.1016/s0168-1656(02)00316-4 